\title{
Pengaruh Return on Asset, Total Assets Turnover, Price Earning Ratio dan Dividend Per Share Terhadap Harga Saham (Studi Empiris pada Perusahaan Manufaktur Sub Sektor Pertambangan yang Terdaftar di BEI Periode 2015-2019
}

\author{
Tamara Irna Sari ${ }^{1}$, Isbandini Veterina ${ }^{2}$ \\ 1,2 Program Studi Manajemen Keuangan, STIE Indonesia Banking School, \\ Jakarta, Indonesia.
}

\begin{abstract}
Abstrak. Penelitian ini bertujuan untuk mengetahui pengaruh Return on Asset (ROA), Total Asset Turn Over (TATO), Price Earning Ratio (PER), dan Dividen Per Share (DPS) terhadap Harga Sabam pada perusabaan sub sektor pertambangan di Bursa Efek. Indonesia periode tabun 2015-2019 dan menggunakan sampel pada 17 perusahaan yang sesuai kriteria. Model analisis data serta pengujian hipotesis menggunakan statistic deskriptif, uji asumsi klasik, uji regresi linier berganda. Uji hipotesis menggunakan bantuan perangkat lunak Microsoft Excel 2016, dan Statistical Package for Social Sciences (SPSS) versi 23.0. Teknik pengambilan sampel menggunakan purposive sampling. Hasil penelitian membuktikan bahwa, secara parsial dan simultan, Return on Asset (ROA), Total Asset Turn Over (TATO), Price Earning Ratio (PER), dan Dividend Per Share (DPS) berpengaruh signifikan terhadap Harga Saham.
\end{abstract}

Kata kunci: ROA; TATO; PER; DPS; Harga Saham; Pertambangan.

\begin{abstract}
This study aims to see the effect of the effect of Return on Asset (ROA), Total Asset Turn Over (TATO), Price Earning Ratio (PER), and Dividend Per Share (DPS) on share prices in mining sub-sector companies on the Indonesia Stock Exchange for the period of year. 2015-2019 and using a sample of 17 companies that match the criteria. Model data analysis and hypothesis testing using descriptive statistics, classical assumption test, multiple linear test. The test used the Microsoft Excel 2016 software assisted bypothesis, and the Statistical Package for Social Sciences (SPSS) version 23.0. The sampling technique used purposive sampling. The results prove that partially and simultaneously, Return on Asset (ROA), Total Asset Turn Over (TATO), Price Earning Ratio (PER), and Dividend Per Share (DPS) have a significant effect on stock prices.
\end{abstract}

Keywords: ROA; TATO; PER; DPS; Stock Price; Mining.

*Corresponding author. Email: tamarairnasari@gmail.com ${ }^{1}$ 


\section{Pendahuluan}

Semakin berkembang dan maju pasar modal suatu negara, semakin baik pula ekonomi suatu negara. Salah satu alternatif yang bisa dipilih untuk berinvestasi di pasar modal yaitu, dengan pembelian saham. Salah satu faktor pendukung dalam kelangsungan bisnis suatu perusahaan adalah bagian dari ketersediannya dana atau modal, salah satu sumber dana yang dapat diperoleh oleh perusahaan yaitu, dengan menjual surat berharga berupa saham ataupun obligasi kepada masyarakat pasar modal.

Menurut Undang-Undang Nomor 8 tentang Pasar Modal yang menjelaskan bahwa, Pasar Modal adalah suatu kegiatan yang bersangkutan dengan penawaran umum dan juga perdagangan efek, perusahaan publik yang berkaitan dengan efek yang diterbitkannya, serta lembaga dan juga profesi yang berkaitan dengan efek. Lain hal yang dimaksud dengan efek pada pasal 1 ayat (5) adalah tentang surat berharga, yaitu beberapa diantaranya; surat pengakuan utang, surat berharga komersial, saham, obligasi, tanda bukti utang, unit penyertaan kontrak investasi kolektif, kontrak berjangka atas efek, dan setiap derivatif dari efek. Menurut (Tandelilin, 2010).

\section{Berdasarkan laporan tahunan PricewaterhouseCoopers di sektor} pertambangan yang dapat disimpulkan bahwa industri pertambangan merupakan salah satu sektor industri yang memiliki kontribusi besar bagi Indonesia, mulai dari peningkatan aktivitas ekonomi, peningkatan pendapatan ekspor, peluang kerja, sumber pendapatan, pembangunan daerah serta anggaran daerah dan pusat. Sektor pertambangan memiliki daya saing yang tinggi di tingkat nasional serta arena internasional. Pemimpin Global Mining di PwC, Jock O 'Callaghan, mengatakan bahwa tidak ada keraguan bahwa tahun 2015 merupakan tahun yang sangat menantang bagi sektor pertambangan. Hasil perbandingan dengan tahun sebelumnya, terjadi penurunan harga komoditas sebesar 25\%. (PricewaterhouseCoopers, 2016).

Penurunan Indeks Harga Saham Gabungan (IHSG) mencapai 12,39 persen sejak 2 Januari 2015. Lemahnya ekonomi global dan nasional menjadi penyebab dari penurunan IHSG. Pertengahan tahun, nilai tukar rupiah menembus angka terendah sejak krisis moneter tahun 1998 di level Rp. 14.728 per dolar AS. IHSG juga terseret ke bawah. Bahkan, beberapa sektor harus turun jika dibandingkan dengan IHSG dan tidak ada indeks saham sektoral di BEI yang mencatat pengembalian positif sepanjang 2015 (Tofler, 2015).

Return on Asset (ROA) adalah rasio yang menunjukan hasil (return) atas jumlah aktiva yang digunakan dalam perusahaan. Return on Asset juga menunjukan efektivitas manajemen dalam menggunakan aktiva untuk memperoleh pendapatan serta dapat memberikan ukuran yang lebih baik atas profitabilitas perusahaan (Kasmir, 2017).

Penelitian yang dilakukan oleh (Irman, 2020) menyatakan bahwa Current Ratio dan Total Asset, Turn Over berpengaruh positif signifikan terhadap Return on Assets, sedangkan Debt to Equity Ratio tidak berpengaruh negatif terhadap Return on Assets. Selanjutnya menurut penelitian yang dilakukan oleh (Rahmanto, 2017) menyatakan bahwa ROA dan DER berpengaruh terhadap harga saham.

Dalam meningkatkan penjualan, pasti akan membutuhkan tambahan asset. Sehingga perusahaan membutuhkan rasio aktivitas untuk menggambarkan hubungan antara tingkat operasi perusahaan (sales) dengan aset yang dibutuhkan untuk menunjang kegiatan operasi perusahaan tersebut. Fitriansyah, et al (2016) menjelaskan hasil penelitian yang dilakukannya bahwa Total Asset Turn Over tidak berpengaruh signifikan terhadap harga saham. Perputaran total aktiva diukur dari volume penjualan, artinya kemampuan semua aktiva dalam menciptakan penjualan belum tentu dapat meningkatkan laba karena ada sebagian laba tersebut digunakan untuk membayar hutang perusahaan.

Investor dapat memilah-milah saham sebelum berinvestasi dalam suatu perusahaan agar nantinya mendapatkan keuntungan yang besar di masa yang akan datang. Hal ini dapat dipertimbangkan dengan menggunakan Price Earning Ratio dimana rasio ini menunjukkan penilaian pasar dari potensi pertumbuhan perusahaan dan prospek laba dimasa yang akan 
datang. (Fiona Felicia Harpono \& Teddy Chandra, 2019) menjelaskan hasil penelitian yang dilakukannya bahwa Price Earning Ratio tidak berpengaruh signifikan terhadap harga saham.

Dividen merupakan suatu imbalan atau balas jasa yang diberikan oleh perusahaan kepada para pemegang saham, yang berasal dari laba yang dihasilkan perusahaan, yang mana salah satu keuntungan yang akan diperoleh investor ketika berinvestasi pada saham, sehingga jumlah dividen yang dibagikan kepada para pemegang saham sesuai dengan jumlah saham yang dimiliki oleh masing - masing pemegang saham. (Fiona Felicia Harpono \& Teddy Chandra, 2019) menjelaskan hasil bahwa Dividen Per Share berpengaruh signifikan terhadap harga saham dikarenakan nilai sig t sebesar $0,005<$ sig $\alpha=0,05$.

Perubahan harga saham akibat suatu keputusan yang diambil alih oleh manager, sehingga terdapatnya suatu kondisi dimana kekuasaan dan juga informasi managerlah yang lebih banyak mendapatkan dibandingkan investor. Dengan adanya asymmetric information theory, membuat manager didalam suatu perusahan lebih leluasa dalam bertindak untuk menentukan strategi pada capital structure, dikarenakan manager lebih memiliki kekuasaan dan juga informasi yang ada didalam perusahaan (Suhendro, 2006).

Penelitian ini bertujuan untuk mengidentifikasi serta menganalisis secara parsial dan simultan pengaruh dari Return on Asset, Total Asset Turn Over, Price Earning Ratio, dan Dividend Per Share terhadap harga saham di perusahaan manufaktur sub sector pertambangan yang terdaftar di BEI periode 2015-2019. Uji hipotesis pada penelitian ini menggunakan bantuan perangkat lunak Microsoft Excel 2016, dan Statistical Package for Social Sciences (SPSS) versi 23.0. Teknik pengambilan sampel menggunakan purposive sampling.

Sampel yang digunakan merupakan perusahaan yang bergerak di bidang pertambangan. secara parsial Return on Asset (ROA), Total Asset Turn Over (TATO), Price Earning Ratio (PER), dan Dividend Per Share (DPS) berpengaruh signifikan terhadap Harga Saham. Sedangkan secara simultan atau bersama-sama Return on Asset (ROA), Turn Asset Turn Over (TATO), Price Earning Ratio (PER) dan Dividend Per Share (DPS) berpengaruh signifikan terhadap Harga Saham.

\section{Literature Review}

\section{Teori Sinyal (Signalling Theory)}

Bagi investor dan pelaku bisnis, elemen penting adalah informasi. Informasi yang dibutuhkan berupa tulisan, atau ilustrasi, kondisi masa depan, sekarang, dan kondisi masa lalu yang bertujuan bagi efek pasar dan pertumbuhan perusahaan. Investor di pasar modal membutuhkan fakta, yang berguna, lengkap, akurat dan terpercaya sebagai alat analisis untuk membuat keputusan investasi. Alasan perusahaan mempublikasikan laporan keuangan kepada pihak eksternal dikatakan sebagai teori sinyal. Pemberian informasi oleh perusahaan didorong karena lebih tau kondisi dalam dan pencapaian masa depan yang dikatakan sebagai adanya asimetri informasi. (Fahmi, 2015). Perusahaan dalam teori Sinyal menyarankan harus memberikan sinyal kepada pengguna laporan keuangan. Bentuk dari sinyal yang diberikan berupa kondisi perusahaan kepada pemilik atau pihak yang berkepentingan. Pemberian sinyal dapat dilakukan melalui pengungkapan informasi akuntansi seperti laporan keuangan, laporan yang telah dilakukan oleh manajemen untuk mewujudkan keinginan pemilik, atau bisa juga berbentuk promosi dan informasi lain tentang kondisi yang lebih baik dari perusahaan lain

\section{Pasar Modal}

Pasar modal adalah pasar untuk berbagai instrumen keuangan jangka panjang yang dapat diperdagangkan, baik obligasi, ekuitas, reksadana, instrumen derivatif dan lain sebagiannya. Pasar modal adalah media pendanaan untuk perusahaan dan lembaga lain (misal, pemerintah), dan sebagai media untuk kegiatan investasi. Dengan demikian pasar modal menyediakan berbagai fasilitas dan infrastruktur kegiatan jual beli dan kegiatan terkait lainnya (Sundjaja, Barlian, \& Sundjaja, 2012). Pada umumnya pasar modal sama dengan pasar lainnya, sebagai tempat pertemuan antara penjual dan pembeli. Sedangkan menurut Pass dan Lower, mendefinisikan pasar modal sebagai 
media untuk membeli dan menjual surat utang korporasi dan ekuitas serta surat utang pemerintah (Rivai, Modding, Veithzal, \& Mariyanti, 2013). Dari beberapa pengertian di atas maka dapat ditarik kesimpulan bahwa pasar modal adalah sarana untuk melakukan suatu aktivitas yang berhubungan dengan penawaran umum dan perdagangan instrument keuangan jangka panjang seperti obligasi, ekuitas, reksadana, instrumen derivatif dan lain sebagiannya.

\section{Harga Saham}

Menurut Brigham dan Houston (2015) harga saham menentukan kekayaan pemegang saham. Memaksimalkan kekayaan pemegang saham berarti memaksimalkan harga saham perusahaan. Harga suatu saham pada waktu tertentu akan tergantung pada arus kas yang diharapkan akan diterima di masa depan oleh investor "rata-rata" jika investor membeli saham. Harga saham dibentuk melalui mekanisme permintaan dan penawaran di pasar modal. Jika suatu saham mengalami kelebihan permintaan, maka harga saham cenderung naik. Sebaliknya, jika kelebihan pasokan maka harga saham cenderung turun (Sartono, 2014). Sedangkan menurut Husnan dan Pudjiastuti (2015) harga saham adalah nilai sekarang dari pendapatan yang akan diterima oleh investor di masa depan. Jadi, dapat disimpulkan bahwa, harga saham adalah nilai sekarang yang terjadi di pasar saham dan dibentuk melalui mekanisme permintaan dan penawaran serta harga tinggi rendahnya ditentukan oleh pelaku pasar.

\section{Laporan Keuangan}

Dalam Standar Akuntansi Keuangan (SAK) No.1 (2017) menyatakan bahwa "Laporan keuangan merupakan bagian dari proses pelaporan keuangan. Laporan keuangan yang lengkap biasanya meliputi neraca, laporan laba rugi, laporan perubahan posisi keuangan (yang dapat disajikan dalam berbagai cara misalnya, sebagai laporan arus kas, atau laporan arus dana), catatan dan laporan lain serta materi penjelasan yang merupakan bagian integral dari laporan keuangan".

Menurut Kasmir (2016), laporan keuangan adalah kondisi keuangan perusahaan dalam suatu periode tertentu yang ditunjukkan oleh laporan. Sedangkan menurut Fahmi (2015), laporan keuangan adalah gambaran kondisi laporan keuangan yang diinformasikan perusahaan untuk menunjukkan kinerja keuangan perusahaan tersebut. Terdapat pula tujuan dari laporan keuangan yaitu untuk memberikan informasi mengenai posisi keuangan, kinerja keuangan dan arus kas entitas yang bermanfaat bagi pengguna laporan keuangan dalam pembuatan keputusan ekonomi.

\section{Metodologi Penelitian}

Jenis penelitian ini merupakan data kuantitatif berupa data sekunder yang diperoleh dari laporan keuangan tahunan yang telah terdaftar di Bursa Efek Indonesia periode 2015-2019 dengan metode observasi tidak langsung. Dan dalam penelitian ini, model dalam menganalisis data untuk pengujian hipotesis menggunakan statistic deskriptif, uji asumsi klasik, uji regresi linier berganda. Serta Adapun uji hipotesis yang dilakukan dengan bantuan perangkat lunak Microsoft Excel 2016 dan Statistical Package for Sosial Sciences (SPSS) versi 23.0. populasi serta sampel yang digunakan pada penelitian ini diperoleh dari laporan keuangan yang terdapat di Bursa Efek Indonesia periode 2015-2019 yang merupakan perusahaan go public. Teknik dalam pengambilan sampel menggunakan teknik purposive sampling dan diperoleh 17 perusahaan yang sesuai dengan kriteria untuk dijadikan sebagai sampel dalam 4 tahun penelitian, sehingga jumlah observasi yang diperoleh sebanyak 85 observasi. Sugiyono (2016) purposive sampling diartikan sebagai teknik penentuan sampel dengan terlebih dahulu menentukan kriteria-kriteria atau pertimbangan tertentu. Adapun kriteria dari perusahaan manufaktur yang dijadikan sampel adalah sebagai berikut:

1. Perusahaan manufaktur sektor pertambangan yang terdaftar di Bursa Efek Indonesia periode 2015-2019.

2. Perusahaan yang menyediakan data yang digunakan sebagai variabel penelitian.

3. Perusahaan yang mengeluarkan laporan keuangan dalam bentuk Rupiah.

4. Perusahaan yang tidak mengalami kerugian selama periode tahun 2015-2019.

5. Laporan keuangan yang digunakan adalah 
laporan keuangan yang sudah di audit.

\section{Hasil dan Pembahasan}

Data populasi yang digunakan dalam penelitian ini berjumlah 47 perusahaan pertambangan, dengan sampel berjumlah 11 perusahaan dengan periode 5 tahun (2015 - 2019) yang telah ditentukan dengan kriteria pada teknik purposive sampling. Nama-nama perusahaan yang terpilih sebagai sampel antara lain, sebagai berikut:

Tabel 1. Sampel Data Perusahaan

\begin{tabular}{|c|c|c|c|}
\hline $\begin{array}{l}\text { No } \\
1\end{array}$ & $\begin{array}{l}\text { Nama Perusahaan } \\
\text { PT B ara Jaya Internasional Tbk }\end{array}$ & $\begin{array}{l}\text { Kode Emiten } \\
\text { ATPK }\end{array}$ & $\begin{array}{l}\text { Sektor } \\
\text { B atu B ara }\end{array}$ \\
\hline 2 & PT Bukit Asam Tbk & PTBA & B atu B ara \\
\hline 3 & PT Golden Eagle Energy Tbk & SMMT & B atu B ara \\
\hline 4 & PT Ratu Prabu Energi Tbk & ARTI & Minyak dan Gas \\
\hline 5 & PT Elnusa Tbk & ELSA & Minyak dan Gas \\
\hline 6 & PT Mitra Investindo Tbk & MITI & Minyak dan Gas \\
\hline 7 & PT Radi ant Utama Interinsco Tbk & RUIS & Minyak dan Gas \\
\hline 8 & PT Aneka Tambang Tbk & ANTM & Logam dan Mineral \\
\hline 9 & PT SMR Utama Tbk & SMRU & Logam dan Mineral \\
\hline 10 & PT Timah Tbk & TINS & Logam dan Miner al \\
\hline & PT Citatah Tbk & CTTH & B atu-batuan \\
\hline
\end{tabular}

Sumber: www.idx.co.id

Sebelum dilakukan analisis lebih lanjut, pada deskripsi data statistik terdiri dari minimum, maximum, mean, standart deviation. Terdapatnya jumlah data yang valid disetiap variabel sebesar 55. Yang menunjukkan hasil uji statistika deskriptif bahwa variabel harga saham sebagai variabel dependen memiiliki nilai minimum sebesar 50 dimiliki oleh PT Mitra Investindo Tbk pada tahun 2017 dan nilai maximum sebesar 12500 yang dimiliki PT Bukit Asam Tbk pada 2016. Secara keseluruhan diperoleh nila rata-rata sebesar 947,15 dengan standar deviasi sebesar 2321,512. Hal tersebut menunjkkan bahwa rata - rata harga saham perusahaan sebesar $94715 \%$ dalam suatu periode.

Setelah dilakukan pengujian asumsi klasik dapat diketahui bahwa data tidak terdapat multikoliniearitas dan tidak terjadi autokorelasi. Oleh karena itu data yang tersedia telah memenuhi syarat untuk menggunakan model regresi linear berganda. maka selanjutnya dilakukan pengujian dengan menggunakan regresi linier berganda untuk mengetahui pengaruh variabel dependen $(\mathrm{Y})$ yaitu harga saham terhadap variabel independen $(\mathrm{X})$ yaitu Return on Asset (X1), Total Asset Turn Over (X2), Price Earning Rasio (X3), Dan Dividend Per Share (X4).

Hasil analisis dari pengujian hipotesis Return on Asset (X1), Total Asset Turn Over (X2), Price Earning Rasio (X3), Dan Dividend Per Share (X4) berpengaruh signidikan terhadap Harga Saham secara parsial. Sedangkan pengaruh dari Return on Asset (X1), Total Asset Turn Over (X2), Price Earning Rasio (X3), Dan Dividend Per Share (X4) juga berpengaruh signifikan terhadap Harga Saham yang dilakukan secara simultan atau bersama-sama.

Hasil penelitian menunjukkan bahwa nilai signifikansi (sig) sebesar 0,000 . Oleh karena nilai signifikansi $0,000<0,05$. Maka dapat disimpulkan bahwa secara simultan atau bersama-sama Return on Asset (X1), Total Asset Turn Over (X2), Price Earning Rasio (X3), Dan Dividend Per Share (X4) berpengaruh signifikan terhadap harga saham pada perusahaan sektor pertambangan periode $2015-2019$.

Hasil analisis regresi linier berganda tersebut dapat dilihat dari Adjusted R Square sebesar 0,511 yang menunjukkan bahwa variabel independen Return on Asset (ROA), Total Asset Turn Over (TATO), Price Earning Rasio (PER), dan Dividend Per Share (DPS) mampu menjelaskan sebesar 51,1\% terhadap variabel dependen yaitu Harga Saham. Maka apabila keempat variabel tersebut meningkat secara bersama - sama maka akan terjadi perubahaan terhadap Harga Saham. Sisanya 48,9\% dipengaruhi oleh variabel lain diluar model yang tidak disebutkan dalam penelitian ini. seperti: Earning Per Share (EPS), Return on Equity (ROE), Net Profit Margin (NPM), dan lainnya.

\section{Kesimpulan}

Berdasarkan hasil penelitian pengaruh Return on Asset (ROA), Total Asset Turn Over (TATO), Price Earning Rasio (PER), dan Dividend Per Share (DPS) terhadap Harga Saham pada perusahaan sektor pertambangan di Bursa Efek Indonesia periode tahun 2015 - 2019. Berdasarkan hasil 
perhitungan yang telah dilakukan, maka dapat diambil kesimpulan sebagai berikut:

1. Secara parsial Return on Asset berpengaruh signifikan terhadap Harga Saham pada perusahaan sektor pertambangan di Bursa Efek Indonesia periode tahun 2015 - 2019.

2. Secara parsial Total Asset Turn Over berpengaruh signifikan terhadap Harga Saham pada perusahaan sektor pertambangan di Bursa Efek Indonesia periode tahun 2015 - 2019.

3. Secara parsial Price Earning Rasio berpengaruh signifikan terhadap Harga Saham pada perusahaan sektor pertambangan di Bursa Efek Indonesia periode tahun 2015 - 2019 .

4. Secara parsial Dividend Per Share berpengaruh signifikan terhadap Harga Saham pada perusahaan sektor pertambangan di Bursa Efek Indonesia periode tahun 2015 - 2019 .

5. Secara simultan atau bersama-sama Return on Asset (ROA), Total Asset Turn Over (TATO), Price Earning Rasio (PER), dan Dividend Per Share (DPS) berpengaruh signifikan terhadap Harga Saham pada perusahaan sektor pertambangan di Bursa Efek Indonesia periode tahun 2015 - 2019.

\section{Daftar Pustaka}

Agustin, I. (2019). The Integration of Fundamental and Technical Analysis in Predicting The Stock Price. Jurnal Manajemen Maranatha, Vol. 18, No. 2, 93-102.

Alaagam, A. (2019). The Relationship Between Profitability and Stock Prices: Evidence from the Saudi Banking Sector. Research Journal of Finance and Accounting, Vol. 10, No. 14, 91-101.

Aldin, I. (2019). IHSG Turun 0,5\%, Sektor Pertambangan dan Perbankan Pimpin Penurunan. Retrieved from Katadata.co.id: https://katadata.co.id/happyfajrian/fina nsial/5e9a5039cbcbd/ihsg-turun-05sektor-pertambangan-dan-perbankanpimpin-penurunan
Alipudin, A., \& Oktaviani, R. (2016). Pengaruh EPS, ROE, ROA dan DER Terhadap Harga Saham pada Perusahaan Sub Sektor Semen yang Terdaftar di BEI. Jurnal Ilmiah Akuntansi Fakultas Ekonomi, Vol. 2, No. 1, 1-22.

Al-Qudah, H. (2020). The Impact of Financial Performance of Stock Prices of Jordanian Islamic Banks (During Periode from 2010 to 2018). International Journal of Economics and Financial Issues, Vol. 10, Issue 1, 228-234.

Alwi, \&. I. (2008). Pasar Modal Teori dan Aplikasi. Jakarta: Yayasan Pancur Siwah.

Ani, N., Trianasari, \& Cipta, W. (2019). Pengaruh ROA dan ROE Serta EPS Terhadap Harga Saham Sektor Pertambangan Yang Terdaftar di BEI. Bisma: Jurnal Manajemen, Vol. 5, N0. 2, 148-157.

Arkan, T. (2016). The Importance of Financial Ratios in Predicting Stock Price Trends: A Case Study in Emerging Markets. Finanse, Rynki Finansowe, Ubezpieczenia nr, 1/2016 (79), 13-26.

Asmirantho, E., \& Somantri, O. (2017). The Effect of Financial Performance on Stock Price at Pharmaceutical Sub-Sector Company Listed in Indonesia Stock Exchange. Jurnal Ilmiah Akuntansi Fakultas Ekonomi, Vol. 3, No. 2, 94-107.

Astuti, O. D. (2018). Pengaruh Return on Asset (ROA), Earning Per Share (EPS) dan Net Profit Margin (NPM) Terhadap Harga Saham Pada Perusahaan Makanan dan Minuman Yang Terdaftar di Bursa Efek Indonesia (BEI) Periode 2014-2017. Jurnal Ekonomi Manajemen, Vol. 4, No. 2, 134142.

Baridwan, Z. (2015). Intermediate Accounting, Edisi 8, Cetakan Ketujuh. Yogyakarta: BPFE-Yogyakarta. 
Brigham, E. F., \& Houston, J. F. (2015). Fundamentals of Financial Management 14th Edition. Mason: South-Western Cengange Learning.

Dang, N. H., \& Tran, M. D. (2018). Investigation of The Impact of Financial Information Relevance on Stock Prices: The Case of Vietnam. The 5th IBSM International Conference on Business, Management and Accounting, 423-437.

Darmadji, C. \&. (2012). Pasar Modal Di Indonesia. Jakarta: Salemba Empat.

Fahmi, I. (2015). Pengantar Manajemen Keuangan Teori dan Soal Jawab. Bandung: Alfabeta.

Fakharuddin, D. T. (2012). Pasar Modal Di Indonesia. Jakarta: Salemba Empat.

Fiona Felicia Harpono \& Teddy Chandra. (2019). Analisis Pengaruh DER, ROE, PER, EPS ,dan DPS Terhadap Harga Saham Pada Perusahaan Sub Sektor Kesehatan Dan Pertambangan Yang Terdaftar Di BEI Tahun 2010-2017. pp. Vol.3, No.1.

Halim, A. (2015). Manajemen Keuangan Bisnis: Konsep dan Aplikasinya. Jakarta: Mitra Wacana Media.

Hanafi, M., \& Halim, A. (2014). Analisis Laporan Keuangan, Edisi Tujuh. Yogyakarta: UPP AMP YKPN.

Harahap, S. (2015). Analisis Kritis atas Laporan Keuangan, Edisi 1-10. Jakarta: Rajawali Pers.

Harahap, S. S. (2010). Analisis Kritis Atas Laporan Keuangan. Cetakan Kedua Belas. Jakarta: PT. Raja Grafindo Persada.

Hartono, J. (2016). Teori Portofolio dan Analisis Investasi, Edisi Kesepuluh. Yogyakarta: BPFE.
Hung, D., Ha, H., \& Binh, D. (2018). Impact of Accounting Information on Financial Statements to the Stock Price of the Energy Enterprises Listed on Vietnam's Stock Market. International Journal of Energy Economics and Policy. 8(2), 1-6.

Husnan, S., \& Pudjiastuti, E. (2015). Dasardasar Manajemen Keuangan, Edisi Ketujuh. Yogyakarta: UPP STIM YKPN. Ikatan Akuntansi Indonesia. (2017). Standar Akuntansi Keuangan. Jakarta: Salemba Empat.

Irman, M. (2020). Analysis On The Influence Of Current Ratio, Debt to Equity Ratio and Total Asset Turnover Toward Return on Assets On The Otomotive and Component Company That Has Been Registered In Indonesia Stock Exchange Within 20112017. pp. 36-44.

Kasmir. (2016). Analisis Laporan Keuangan. Jakarta: PT. Raja Grafindo Persada.

Kasmir. (2017). Analisis Laporan Keuangan. Jakarta: PT. Raja Grafindo Persada.

Maria. (2014). Pengaruh Total Assets Turn Over (TATO) dan Return on Asset (ROA) terhadap Harga Saham pada Perusahaan Pertambangan yang terdaftar di BEI Tahun 2010-2012. Jurnal Akuntansi, vol. 1, No. 1.

Munawir, S. (2015). Analisis Laporan Keuangan. Jakarta: Salemba Empat.

Muthiah, A. (2018). Pengaruh DER, PER, ROE dan arus kas operasi terhadap harga saham perusahaan subsektor konstruksi bangunan dan subsektor property yang terdaftar di BEI tahun 2011 - 2015. pp. Vol. 14, No. 2.

Otoritas Jasa Keuangan. (1995). Undangundang Nomor 8 Tahun 1995 tentang Pasar Modal. Retrieved from Otoritas Jasa Keuangan: https://www.ojk.go.id/id/kanal/pasarmodal/regulasi/undangundang/Pages/undang-undang-nomor-8- 
tahun-1995-tentang-pasar-modal.aspx

Otoritas Jasa Keuangan. (2016). Surat Edaran Otoritas Jasa Keuangan Nomor 30/SEOJK.04/2016. Retrieved from Otoritas Jasa Keuangan: https://www.ojk.go.id/id/kanal/pasarmodal/regulasi/surat-edaranojk/Pages/SEOJK-tentang-Bentuk-danIsi-Laporan-Tahunan-Emiten-AtauPerusahaan-Publik.aspx

PricewaterhouseCoopers. (2016). PwC: Tahun 2015 Sebagai Tahun Terburuk Bagi Sektor Pertambangan. Retrieved 2020, from PwC Indonesia: https://www.pwc.com/id/en/mediacentre/pwc-in news/2016/indonesian/pwc---tahun2015-sebagai-tahun-terburuk-bagisektor-pertambangan.html

Puspitaningtyas, Z. (2017). Is Financial Performance Reflected in Stock Prices? Advances in Economics, Business and Management Research, Vol. 40, 17-28.

Putri, N., \& Saryadi. (2017). Pengaruh Return on Assets (ROA), Return on Equity (ROE), Net Profit Margin (NPM) dan Earning Per Share (EPS) Terhadap Harga Saham. Jurnal Ilmu Administrasi Bisnis, 1-12.

Rahmanto, B. T. (2017). Influence Analysis of Fundamental Information, Company Size and Sales Growth Toward Share Price (Studies in Pharmacy Industry Company Listed in Indonesia Stock Exchange). International Journal of Economic Research, 11-25.

Rivai, V., Modding, B., Veithzal, A., \& Mariyanti, T. (2013). Financial Institution Management. Jakarta: Rajawali Pers.

Sanjaya, S., \& Yuliastanty, S. (2018). Pengaruh Earning Per Share (EPS), Debt to Equity Ratio (DER) dan Return on Equity (ROE) Terhadap Harga Saham. UNES Journal of Social and Economics Research, Vol. 3 , Issue 1,1-13.
Sartono, A. (2014). Manajemen Keuangan Teori dan Aplikasi. Yogyakarta: BPFE.

Sauqi, M., Wahyuningtyas, E., \& Agustina, H. (2018). Kinerja Keuangan Dalam Mempengaruhi Harga Saham pada Industri Perusahaan Logam yang Terdaftar di Bursa Efek Indonesia. Equity: Jurnal Ekonomi, Manajemen, Akuntansi, Vol. 22, No. 1, 37-46.

Sigit. (2019). Saham Sektor Tambang Berguguran, Bukan Karena Faktor Fundamental. Retrieved from IPOTNEWS:

https://www.indopremier.com/ipotnews /newsDetail.php?jdl=Saham_Sektor_Ta mbang_Berguguran_Bukan_Karena_Fak tor_Fundamental\&news_id=110343\&gro up_news $=I P O T N E W S \&$ news_date $=\&$ ta ging_subtype $=$ STOCK\&name $=\&$ search $=$ y_general\&q $=$ TINS, $\% 20$ PTBA,$\% 20$ ADR O,\%20ANTM, \%20ELSA, \%20IN

Sudana, I. (2012). Manajemen Keuangan Perusahaan Teori dan Praktik. Jakarta: Erlangga.

Sugiyono. (2012). Metode Penelitian Bisnis. Bandung: Alfabeta.

Sugiyono. (2016). Metode Penelitian Kuantitatif, Kualitatif dan R\&D. Bandung: PT Alfabeta.

Suhendro, I. d. (2006). Determinasi Capital Structure Pada Perusahaan Manufaktur Di Bursa Efek Jakarta Periode 2000-2004. Jurnal Akuntansi dddan Keuangan Indonesia, 77-105.

Sundjaja, R., Barlian, I., \& Sundjaja, D. (2012). Manajemen Keuangan 2, Edisi 7. Jakarta: Litera Lintas Media.

Suryantini, I. S. (2019). Pengaruh CR, DER, ROA, PER Terhadap Harga Saham Pada Perusahaan Pertambangan DI BEI. ISSN : 2302-8912. 
Suryantini, I. S. (2019). Pengaruh CR, DER, ROA, PER Terhadap Harga Saham Pada Perusahaan Pertambangan DI BEI. EJurnal Manajemen.

Tandelilin, E. (2010). Portofolio dan Investasi. Yogyakarta: Kanusius.

Tandelilin, E. (2017). Portofolio dan Investasi Teori dan Aplikasi. Yogyakarta: PT. Kanisius.

Tofler, A. (2015). Indeks Sektor Pertambangan dan Agribisnis Terbenam Paling Dalam pada 2015. Retrieved 2020, from Bareksa: https://www.bareksa.com/id/text/2015 /12/22/indeks-sektor-pertambangandan-agribisnis-terbenam-paling-dalampada-2015/12257/news

Triawan, R., \& Shofawati, A. (2018). Pengaruh ROA, ROE, NPM dan EPS Terhadap Harga Saham Perusahaan di Jakarta. Jurnal Ekonomi Syariah Teori dan Terapan, Vol. 5, No. 7, 541-555.

Ukhriyawati, C., \& Pratiwi, M. (2018). Pengaruh Return on Asset (ROA), Debt to Equity Ratio (DER) dan Earning Per Share (EPS) Terhadap Harga Saham pada Perusahaan Properti di Bursa Efek Indonesia. Jurnal Equilibira, Vol. 5, No. 2, $1-11$.
Utami, M., \& Darmawan, A. (2018). Pengaruh DER, ROA, ROE, EPS dan MVA Terhadap Harga Saham pada Indeks Saham Syariah Indonesia. Journal of Applied Managerial Accounting, Vol. 2, No. 2, 206-218.

Utari, D., Purwanti, A., \& Prawironegoro, D. (2014). Manajemen Keuangan: Kajian Praktek dan Teori dalam Mengelola Keuangan Organisasi Perusahaan (Edisi Revisi). Jakarta: Mitra Wacana Media.

Wibowo, C., Sukoco, A., Wulandari, A., \& Bhukuth, A. (2018). Stock Price and Performance of Indonesian Banking, Case Study for The Period of 2013-2016. International Journal of Accounting \& Finance in Asia Pasific, Vol. 1, No. 1, 5457.

Zuliarni, S. (2012). Pengaruh Kinerja Keuangan Terhadap Harga Saham Pada Perusahaan Mining and Mining Service Di Bursa Efek Indonesia. Jurnal Aplikasi Bisnis, Vol. 3, No. 1. 